\title{
Reusable Enzymatic Strip for Detection of Arsenic
}

\author{
Vikas Hooda ${ }^{*}$
}

https://orcid.org/0000-0002-9347-7304

\author{
Neelam Verma ${ }^{1}$ \\ https://orcid.org/0000-0001-9997-0987
}

Anjum Gahlaut ${ }^{1}$

https://orcid.org/0000-0002-5979-519X

\author{
Ashish Gothwal1 \\ https://orcid.org/0000-0003-4983-691X \\ ${ }^{1}$ Maharshi Dayanand University, Centre for Biotechnology, Haryana, India. \\ Editor-in-Chief: Paulo Vitor Farago \\ Associate Editor: Luiz Gustavo Lacerda
}

Received: 2020.03.05; Accepted: 2020.12.18.

*Correspondence: advance.biotech@gmail.com; Tel.: +911262393113, +918295558888 (V.H.)

\section{HIGHLIGHTS}

- Arsenic is considered as one of the highly hazardous elements in the environment and a serious carcinogen for the human health.

- An enzymatic method has been described by using arsenite oxidase for arsenic detection.

- Residual activity of the immobilized enzyme was $43 \%$ of the initial activity after being recycled 10 times.

\begin{abstract}
Arsenic is considered as one of the highly hazardous elements in the environment and a serious carcinogen for the human health. More attention has taken towards the arsenic due to its presence in ground water in India, China, Bangladesh, Inner Mongolia and several other regions of the world. It's been a challenge to remove arsenic due to the lack of its efficient detection approach in the complicated environmental matrix. The proposed method describes an enzymatic method for arsenic determination using arsenite oxidase, which catalyzes the oxidation of arsenite to arsenate. Hence, a colorimetric PVC strip with immobilized arsenite oxidase has been developed to detect the arsenic concentration and also having potential for the field-testing. The influence of the optimal conditions i.e. $\mathrm{pH}$, temperature, storage stability, and reusability of free and immobilized enzyme were evaluated and compared. The results have shown that the stabilities were significantly enhanced compared with free counterpart. Residual activity of the immobilized enzyme was $43 \%$ of the initial activity after being recycled 10 times. We approve that this novel low cost immobilized carrier presents a new approach in large scale applications and expected to act as a model for establishment of indigenous arsenic sensor in miniature form.
\end{abstract}

Keywords: arsenic; arsenite oxidase; PVC strip; groundwater. 


\section{INTRODUCTION}

Arsenic (As) contamination has been evolved as a global threat to environment and a serious toxic to human health reported in many countries and regions [1]. It is studied that over 100 million people have been affected worldwide mainly widespread in South and South East Asia particularly Bangladesh and West Bengal being among the worst affected areas [2]. Arsenic is most commonly found as Arsenate [As (V)] and arsenite [As (III)] species present in aqueous environments [1]. As (III) is considered as to be 60 times more hazardous than As (V) or organic arsenic compounds and hence most toxic to human health and environment [3].The permissible level of arsenic is $10 \mu \mathrm{g} / \mathrm{L}$ (many developing countries still employ a $50 \mu \mathrm{g} / \mathrm{L}$ standard) in drinking water according to US Environmental Protection Agency (EPA) and World Health Organization, but found higher in several sources such as drinking water, irrigation water, vegetables and cereals, fish, meat, milk etc. [4]. Exposure to arsenic can lead to various health concerns including cardiovascular diseases [5], skin lesions [6], arsenicosis [7], various types of cancer and mutagenic effects, hematological side effects [8], hyperkeratosis [9], and many more disorders. Arsenic is registered as priority toxic element under the European Directive on Environmental Quality Standards due to its toxicity [5].

In this context, authentic and selective arsenic detection approaches are of paramount importance to safeguard the public health. Various analytical methods such as hydride generation, laser-induced breakdown spectroscopy (LIBS), atomic force microscopy (AFM), neutron activation analysis (NAA), surface enhanced raman spectroscopy (SERS), atomic absorption spectroscopy (AAS) [10], and capillary Electrophoresis inductively coupled plasma mass spectrometry (ICP-MS) [11], atomic Fluorescence spectroscopy (AFS) and high performance liquid chromatography (HPLC) [12] are used to detect arsenic in environmental samples. Although these techniques are reliable, highly sensitive and can detect even traces of the element but have many drawbacks as these require more time, unsuitable for field testing, requires sophisticated instrumentation and highly skilled personnel. However, these analysis based on the Gutzeit method have been employed in the past and are also slow in providing results (30 sec to $10 \mathrm{~min}$ ). These methods require an expensive set up, experienced personnel and are bound only to laboratory areas. Consequently, it is imperative to develop simple and cost effective alternative methods to detect arsenic that can screen large number of samples in little time. The electrochemical techniques have emerged as a possible means to fulfill these conditions $[13,14]$. Colorimetric methods offer an easy and economical way to quantify arsenic compounds and some of these field test kits are already commercially available. Hence, researchers have thought of better alternative of using enzymatic and biological approaches for arsenic detection that reduce all these problems [15].

Recently, biocatalysts have shown increasingly potential applications in arsenic detection as a more specific alternative [16]. Enzymes can effectively transform and detoxify various metalloids [17]. Immobilized enzymes are gaining enormous attention as they show more stability, unique specificity and increased activity than the native enzyme $[18,19]$. Enzymatic methods overcomes all the drawbacks associated with previous conventional methods as they cost-effective, sensitive, specific, user friendly and monitor large no. of samples with in-field application. Also, immobilized biocatalyst is advantageous over free enzyme as it can be recycled and reused many times by using physio-chemical properties of the supporting matrix and can enhance its activity and stability [20]. Comparing to most of the matrix supports reported in the literature, the proposed matrix is more convenient and efficient for the enzymes stability by providing suitable microenvironment. The matrix comprises a large surface area for molecular recognition and immobilization of enzymes that improves the enzyme catalytic efficiency and loading capacity significantly. This property provides immobilization of more enzymes on their surface and less restriction for diffusion of substrate and product.

Arsenic, being a very toxic metalloid, cannot be degraded into harmless compounds but its chemical or microbial oxidation can lead to less toxic arsenate. Arsenite oxidase (Aio) is considered as an ideal biocatalyst as it has the capability to oxidize and transform more hazardous arsenite [As (III)] to the less harmful toxic arsenate [As (V)] [21]. The arsenite oxidase is a heterotetramer. It consists a large catalytic subunit (AioA) having molybdenum (Mo) centre and a $3 \mathrm{Fe}-4 \mathrm{~S}$ cluster, and a small subunit (AioB) having a Rieske $2 \mathrm{Fe}-2 \mathrm{~S}$ cluster [22]. Arsenite oxidase catalyzes the aerobic oxidation of arsenite that couples its oxidation to the reduction of oxygen to water creating ATP and sometimes $\mathrm{NADH}$ for $\mathrm{CO}_{2}$ fixation [23]. It has been reported that arsenite oxidation produces electrons that pass to the Mo centre, to the 3Fe-4S cluster, the Rieske cluster and finally to an electron acceptor [24,25].

The aim of the present work is to develop a simple, rapid and affordable method for arsenic detection with high sensitivity and specificity. The proposed work provides a laboratory model of enzymatic approach for detection of arsenic compounds in various samples. It involves the use of an enzymatic strip to detect 
arsenic and provides onsite/in situ detection method. Arsenite oxidase enzyme was isolated and partially purified from an arsenic resistant bacterium i.e. Arthrobacter sp.15b. Purified enzyme was immobilized onto a nitrocellulose film using glutaraldehyde as a coupling agent. The improved properties and various parameters of the immobilized enzyme were compared with the free counterpart enzyme. The results have shown that the Immobilization has enhanced the enzyme stability at varying $\mathrm{pH}$ and temperature. Further, the process is economical as the immobilized PVC strip has shown a significant reusability. The PVC strip prepared by this procedure would surely provide a new pathway in fabricating many biosensing devices, biomedical instrumentation and diagnostic kits. This novel approach of immobilizing Aio enzyme onto an effective matrix proves to be highly sensitive for screening arsenic at nano levels. This laboratory model is expected to act as a model for making indigenous arsenic sensor in miniature form.

\section{MATERIAL AND METHODS}

\section{Chemicals and reagents}

Sodium arsenite was from Sigma Aldrich (St. Louis, MO, USA), Nafion, Glutaraldehyde, DCIP (2, 6dichlorophenol indophenol), MES (morpholino ethelenediol sulfonic acid), $\left(\mathrm{NH}_{4}\right)_{2} \mathrm{SO}_{4}, \mathrm{KH}_{2} \mathrm{PO}, \mathrm{KCl}$, $\mathrm{Ca}\left(\mathrm{NO}_{3}\right)_{2}, \mathrm{NaHCO}_{3}$ were from HIMEDIA Lab. Pvt. Ltd. Ninhydrin reagent, Folin-Ciocalteu reagent, ammonium sulphate were from SRL Chemicals, India. All Chemicals and reagents used were of analytical grade and purest quality. Double distilled water (DW) was used for all experiments.

\section{Preparation of Arsenite oxidase}

\section{Crude extraction of arsenite oxidase}

Extraction and purification of Aio from Arthrobacter sp.15b was performed by following the protocol reported by Prasad and coauthors [26]. Briefly, Bacterial isolate was cultured and the trace element solution was added to it maintaining final $\mathrm{pH}$ 7.8. Then the culture was left for incubation for 16 hours at $28{ }^{\circ} \mathrm{C}$ and centrifuged at $4,500 \mathrm{~g}$ for $5 \mathrm{~min}$ at $4{ }^{\circ} \mathrm{C}$ where absorbance of the growth medium recorded as 0.35 at 600 $\mathrm{nm}$. Pellet obtained was further washed thrice with washing buffer $(0.9 \% \mathrm{NaCl}, 0.1 \mathrm{mM} \mathrm{PMSF}, 0.6 \mathrm{mM}$ EDTA and $20 \mathrm{mM}$ Tris- $\mathrm{Cl}$ ), $\mathrm{pH} 8.4$ and centrifuged every time with same conditions. Final pellet suspension was supplemented in $50 \mathrm{~mL}$ of suspension buffer (having $2 \mathrm{mg} \mathrm{mL}-1$ lysozyme) and left for 2 hours at ambient temperature with slight shaking. $\mathrm{MgSO}_{4}(20 \mathrm{mM})$ and $\mathrm{Mg}\left(\mathrm{CH}_{3} \mathrm{COO}\right)_{2}(100 \mathrm{mM})$ were added followed by addition of DNase $(100 \mu \mathrm{g})$ and RNase $(500 \mu \mathrm{g})$. After incubating the extract for half an hour, the suspension was sonicated and the disrupted cell suspension was warmed at $60{ }^{\circ} \mathrm{C}$ for $1 \mathrm{~min}$ in water bath and cooled at once on ice to $4{ }^{\circ} \mathrm{C}$. Cell detritus was separated and clear protein supernatant was stored after centrifuging lysate at $9000 \mathrm{~g}$ for $15 \mathrm{~m}$.

\section{Purification of Arsenite oxidase}

The purification procedure was performed by protocol reported by Prasad and coauthors [26] with some modifications. Total protein solution was undergone with (20-85\%) ammonium sulfate precipitation. Then the precipitate was harvested by centrifugation and resuspended in minimal buffer and dialyzed overnight. $\mathrm{pH}$ of the protein was maintained at 8.4. Next, the solution was further incorporated into gel filtration columnSephadex G-75 equilibrated with buffer solution (having $0.01 \%$ Triton X, $300 \mathrm{mM} \mathrm{NaCl} ; 50 \mathrm{mM}$ Tris.Cl, pH 7). Active fractions were pooled, concentrated and eluted with the same buffer. The purification procedure was performed at $4^{\circ} \mathrm{C}$ to sustain enzyme activity.

\section{Preparation of reusable enzyme strip}

The rectangular strips $\left(15 \times 1 \mathrm{~cm}^{2}\right)$ size was cut from PVC sheet (thickness $\left.0.5 \mathrm{~mm}\right)$. Then the strip was activated by placing it in ethylene diamine $(0.020 \%)$ in water bath under continuous shaking. This provided the amine groups at the PVC surface required for immobilization. Thereafter, the strip was rinsed several times with DW to remove the unbound amines and allowed to dry at ambient temperature.

\section{Immobilization of Arsenite oxidase onto activated PVC strip}

The immobilization scheme for Aio onto activated PVC strip has been shown in Figure 1. Modified PVC strip was activated by incubating with glutaraldehyde solution (2.5\%) for 48 hours at room temperature. 
Then, the activated strip was rinsed with DW to remove unreacted glutaraldehyde. Then $2 \mu \mathrm{L}$ of AiO was casted onto the surface of strip with a micro syringe and allowed to dry at room temperature. After it, $1 \mu \mathrm{L}$ of $5 \%$ Nafion was used as a binder to stably hold the arsenite oxidase on the matrix surface. The excess solvent was left to evaporate before use. The final strip formed will be used for detection method and stored at $4{ }^{\circ} \mathrm{C}$ in a refrigerator until use.

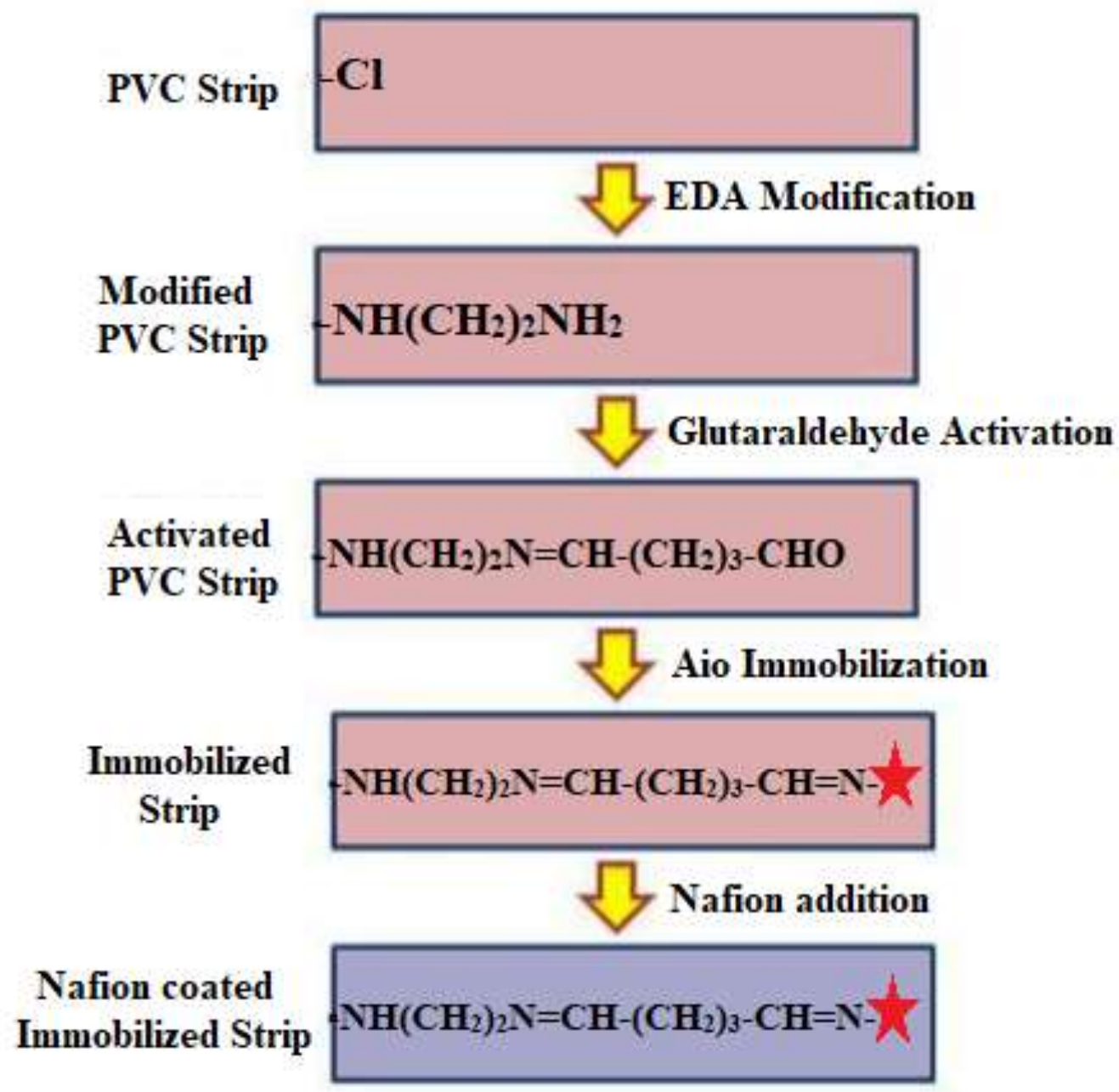

Figure 1. Schematic representation for the immobilization procedure.

\section{Enzyme and protein assay}

Free and immobilized enzyme assay

The enzyme assay for determining the activity was performed by following the protocol reported by Anderson and coauthors [27]. It was based on the principle of the reduction of an artificial electron acceptor DCIP in MES buffer ( $\mathrm{pH}$ 6.0). Activities of both the crude and column purified fractions were calculated by adding enzyme solution into $1 \mathrm{~mL}$ of assay buffer containing DCIP $(60 \mu \mathrm{M}), \mathrm{NaAsO}_{2}(200 \mu \mathrm{M})$ and $50 \mathrm{mM}$ MES (pH 6.0). Arsenite oxidase oxidizes the arsenite and couples to the reduction of oxygen to water that generate ATP and NADH for $\mathrm{CO}_{2}$ fixation. The electrons form arsenite oxidation pass to the Mo centre, then to Rieske cluster and finally to an electron acceptor [22,24]. Absorbance was observed at $600 \mathrm{~nm}$. Heat denatured protein (boiled for $10 \mathrm{~min}$ ) was referred as a control for this experiment.

One unit of Aio activity is described as the enzyme concentration used to oxidize $1 \mu \mathrm{mol}$ of substrate per minute under the standard assay conditions.

\section{Protein assay}

The protein content was measured by Bradford protein assay [28] using Bovine serum albumin as standard. The enzyme concentration immobilized onto the strip was calculated by observing the initial and final protein concentrations in immobilization medium. 


\section{Effect of $\mathrm{pH}$ and temperature}

Effect of $\mathrm{pH}$ was observed by incubating the enzyme with buffer of different $\mathrm{pH}$ and checked from $\mathrm{pH} 3$ to $\mathrm{pH}$ 9. Purified Aio was added in assay buffer maintaining same concentration of DCIP $(60 \mu \mathrm{M})$ and $\mathrm{NaAsO}_{2}(200 \mu \mathrm{M})$. Buffering condition in reaction buffer was maintained and attained using various buffer. $\mathrm{pH} 3$ and 4 was maintained by using $50 \mathrm{mM}$ Citrate, $\mathrm{pH} 5$ and 6 was maintained by by $50 \mathrm{mM} \mathrm{MES}, \mathrm{pH} 7$ and 8 by using $50 \mathrm{mM}$ Tris. $\mathrm{Cl}$ and $\mathrm{pH} 9$ was maintained by using $50 \mathrm{mM}$ Borate. Relative activity of Aio was determined at different $\mathrm{pH}$ values [26].

The temperature effect on purified Aio was monitored by incubating at different range of temperature values $\left(10-50{ }^{\circ} \mathrm{C}\right.$ with interval of $5{ }^{\circ} \mathrm{C}$ ) for one hour and the reaction mixture (containing $60 \mu \mathrm{M}$ DCIP, 200 $\mu \mathrm{M} \mathrm{NaAsO} \mathrm{O}_{2}$ and $50 \mathrm{mM}$ MES), $\mathrm{pH} 6.0$ was added. Change in absorbance was observed using spectrophotometer. Greatest change occurred in absorbance was regarded as $100 \%$ activity. Then, relative activity of Aio at several temperatures values was monitored and recorded. The process was performed in a set of triplicates and the results were analyzed as average \pm standard deviation. The relative activity (\%) was measured as a comparison of the residual activity to the initial activity for each sample [26].

\section{Reusability and storage stability}

Reusability property of immobilized Aio was monitored by determining the enzyme activity in successive experimental cycles. After getting each activity, the immobilized strip was rinsed with buffer solution and reintroduced into a fresh suspension. It was done for 10 consecutive cycles. The efficiency of reusability was measured as the difference of initial and final enzyme activity.

Free and immobilized enzyme film were incubated in buffer solution, $\mathrm{pH} 6.0$ at $4{ }^{\circ} \mathrm{C}$ and their activities were measured and compared for 30 days on fixed time periods using the mentioned enzyme assay and the storage stability was analyzed to determine the feasibility of biocatalyst activity in use after a particular duration of storage. Following it, the residual activity was evaluated as a ratio between enzyme activities after storage to their initial activities.

\section{Interference study}

Influence of different chemical agents or metal ions interfering with the activity of Aio was detected with several metal salts. These include effect of Para chloromercuribenzoic acid (pCMB), $\mathrm{CaCl}_{2}, \mathrm{NaCl}, \mathrm{CoCl}_{2}$, $\mathrm{MgCl}_{2}, \mathrm{ZnCl}_{2}, \mathrm{FeSO}_{4}, \mathrm{EDTA}, \mathrm{DEPC}, \mathrm{Na}_{2} \mathrm{Mo}_{4}$ and lodoacetic acid. Their $100 \mathrm{mM}$ stock solution was prepared and the absorbance was recorded before and after the addition of salt solution in reaction buffer containing enzyme. Changes observed were evaluated as percent change in activity.

\section{Percentage recovery}

Reliability of the method was determined by measuring arsenic content in six water samples before and after addition of two different concentration of Aio i.e. $1 \mu \mathrm{g} / \mathrm{mL}$ and $2 \mu \mathrm{g} / \mathrm{mL}$. The Percentage recovery of added Aio was measured.

\section{Precision}

Reproducibility, selectivity and reliability of the present approach was checked by determining the level of arsenic concentration in six samples within a batch (in single run) for same day and between batches i.e. after one week of storage at $-20^{\circ} \mathrm{C}$.

Coefficient of variation (CV) was calculated in both batches using the following formula:

$$
\mathrm{CV}=\sigma \times 100
$$

Where:

$$
\begin{aligned}
& \sigma=\mathrm{SD} \\
& \alpha=\text { mean of series }
\end{aligned}
$$

\section{Application of the developed method}

Arsenic contaminated water samples were collected from different sources. The samples were reacted with enzyme immobilized PVC strip which converted the arsenic into less toxic arsenate form. 
DCIP (2, 6-dichlorophenol indophenol) in MES buffer was added to the reaction mixture and observed at $600 \mathrm{~nm}$ as reported earlier.

\section{RESULTS AND DISCUSSION}

\section{Extraction and Purification of Aio}

Prasad and coauthors [26] has observed that the Aio enzyme shows $10 \%$ of total activity when found in periplasmic space and $90 \%$ of the activity localized in the membrane fraction. Aio was extracted and purified by subjecting to (20-85\%) ammonium sulphate precipitation and further by dialysis and gel filtration chromatography. Fractions of $3 \mathrm{~mL}$ were collected and the protein concentration was observed. The summary of Aio extraction and purification has been provided in Table 1. The enzyme precipitates showed specific activity of $0.023 \mu \mathrm{M} \mathrm{As}(\mathrm{III}) / \mathrm{min} / \mathrm{mg}$ with 1.15 fold purification. Dialysis improved the purification fold of Aio from 1.15 to 12 . Eluted protein fractions were concentrated, evaluated and 0.83 $\mu \mathrm{M} \mathrm{As}(\mathrm{III}) / \mathrm{min} / \mathrm{mg}$ specific activity with 41.5 fold purification was observed. Aio has been purified from several sources by many researches to different extent [29]. Anderson and coauthors [27] has efficiently purified Aio from Alcaligenes faecalis and shown high yield. Further, Ellis and coauthors [22] used the same source A. faecalis for Aio and observed its structure. Muller and coauthors [30] has used $\beta$ proteobacterial strain ULPAs1 as source of Aio. Watson and coauthors [25] has purified Aio from Rhizobium species structure NT-26 and constructed a biosensor. Hence, the purified Aio from Arthrobacter species $15 \mathrm{~b}$ was highly efficient and overall produced 41.5 fold purified enzyme with 0.83 specific activity which is desirable for immobilization procedure.

Table 1. Purification summary of Arsenite oxidase enzyme

\begin{tabular}{lcccc}
\hline $\begin{array}{l}\text { Purification of Arsenite } \\
\text { oxidase }\end{array}$ & $\begin{array}{c}\text { Total protein } \\
(\mathbf{m g})\end{array}$ & $\begin{array}{c}\text { Total activity }(\boldsymbol{\mu M} \\
\mathbf{A s}(\mathbf{I I I}) / \mathbf{m i n})\end{array}$ & $\begin{array}{c}\text { Sp. Activity }(\boldsymbol{\mu M} \\
\mathbf{A s}(\mathbf{I I I}) / \mathbf{m i n} / \mathbf{m g})\end{array}$ & $\begin{array}{c}\text { Purification } \\
\text { fold }\end{array}$ \\
\hline Crude enzyme & 2190 & 45 & 0.02 & 1 \\
Precipitates & 1590 & 37 & 0.023 & 1.15 \\
Dialyzed Precipitates & 117 & 29 & 0.24 & 12 \\
Eluate & 24 & 20 & 0.83 & 41.5 \\
\hline
\end{tabular}

1 One unit of Aio activity is defined as the concentration of enzyme used to oxidize $1 \mu \mathrm{mol}$ of substrate per minute under the standard assay conditions

\section{Optimization of immobilization yield}

Immobilization mechanism of Aio enzyme onto activated PVC strip has been illustrated in Figure 1. Aio enzyme was evaluated for the immobilization capability onto activated PVC membrane. Aio activity was analyzed prior and after to immobilization. The effect of enzyme concentration on the immobilization process was determined and has been shown in Figure 2, where relative activity with different enzyme loading has been illustrated. The final PVC strip immobilized with $3 \mathrm{mg}$ of Aio enzyme extract showed highest activity at the identified specific optimum parameters. This also shows analogously highest immobilization yield which appeared as highest activity. Immobilized enzyme showed conjugation yield of $0.37 \mathrm{mg} / \mathrm{cm}^{2}$ retained about nearly $43 \%$ immobilization yield. The membrane gets saturation point at this concentration and showed a slight declination on further addition of enzyme. This showed good loading efficiency and highly recovered Aio enzyme due to formation of stable crosslinking between the enzyme and the support. Moreover, local surface area of support material was increased by immobilization that diminishes the steric hindrance of the enzyme active site [31]. Then, the prepared membrane was used to study different parameters to find the optimality of the enzyme. Pandey and Bhatt [19] have utilized chitosan nanoparticles to successfully immobilize arsenite oxidase purified from arsenic resistant bacterium that increased the enzyme stability and increased biotransformation. Simeonova and coauthors [32] has purified Aio from arsenite oxidizing strain ULPAs1 and immobilized in calcium alginate beads that offered a promising way for implementation of various methods in arsenic remediation. Bienzymatic immobilization has also done on carbon electrode by covalently bonding that produced efficient results $[33,34]$. 


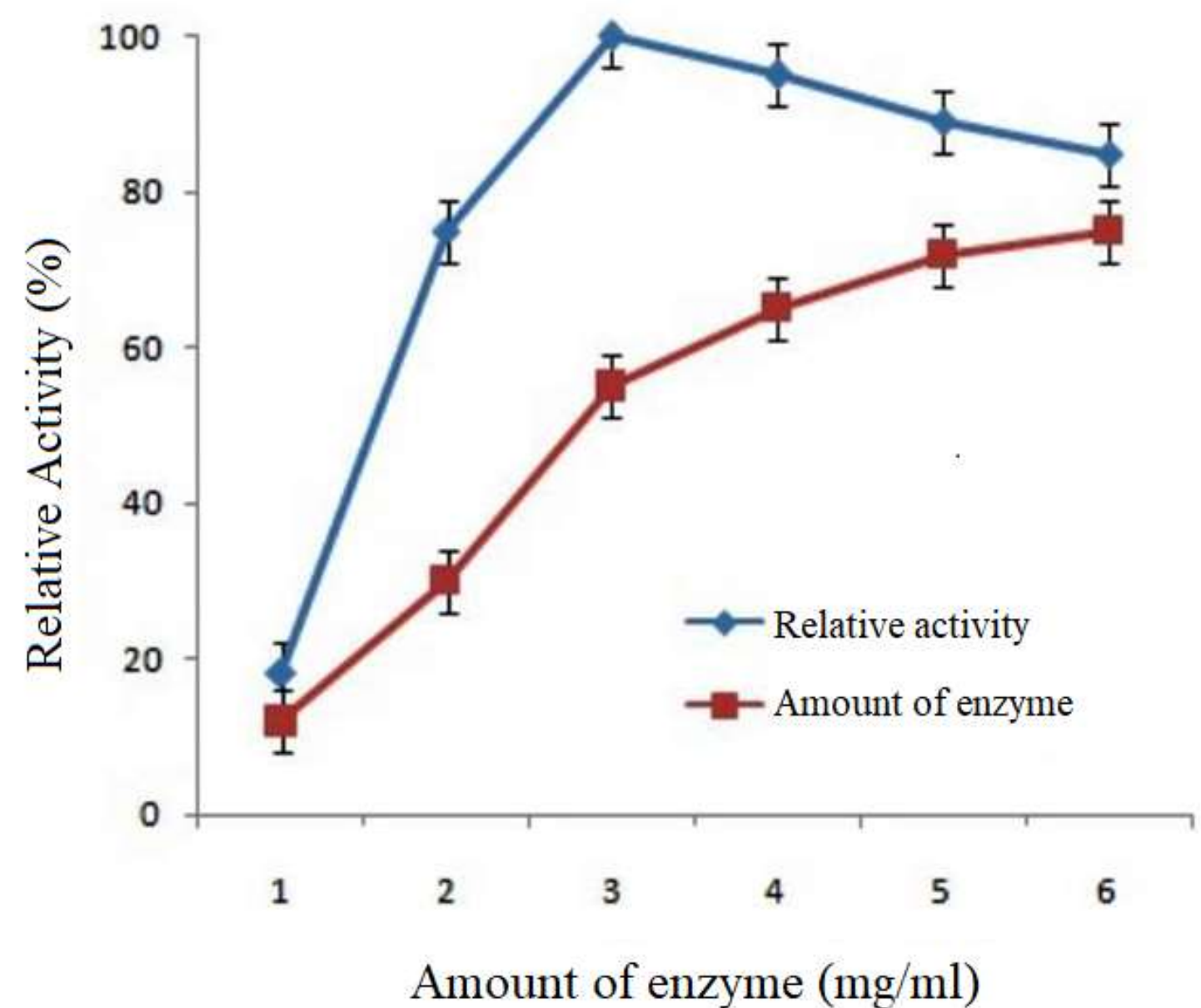

Figure 2. Effect of enzyme concentration on immobilization process. Error bars representing standard deviation of three values.

\section{$\mathrm{pH}$ and temperature activity profile}

A comparative study was done between free and immobilized enzymes in terms of $\mathrm{pH}$ and Temperature. $\mathrm{pH}$ of the reaction suspension is a crucial parameter for enzyme stability as it can affect the dissociation state of the enzyme. The effect of $\mathrm{pH}$ values on enzyme activity on PVC strip was determined in a range between 3 and 9 with regular increment of 0.5 as shown in Figure 3. Free enzyme showed the highest activity at $\mathrm{pH} 6$ while immobilized enzyme exhibited maximum activity at $\mathrm{pH}$ 7.0. This shift in $\mathrm{pH}$ values after immobilization might be due to changes in acidic and basic amino side chain around the enzyme active site in the microenvironment. Purified enzyme was remained active at wide range of $\mathrm{pH}$ values i.e. 5 to 8 and showed high activity. Prior to this range (at $\mathrm{pH} 4)$ and after this range (at $\mathrm{pH} 9)$ enzyme showed significant activity loss. Broad and shift to high $\mathrm{pH}$ range showed by immobilized Aio is of paramount importance for commercial applications. Similar $\mathrm{pH}$ dependence has been observed by previous researches $[32,35]$. 


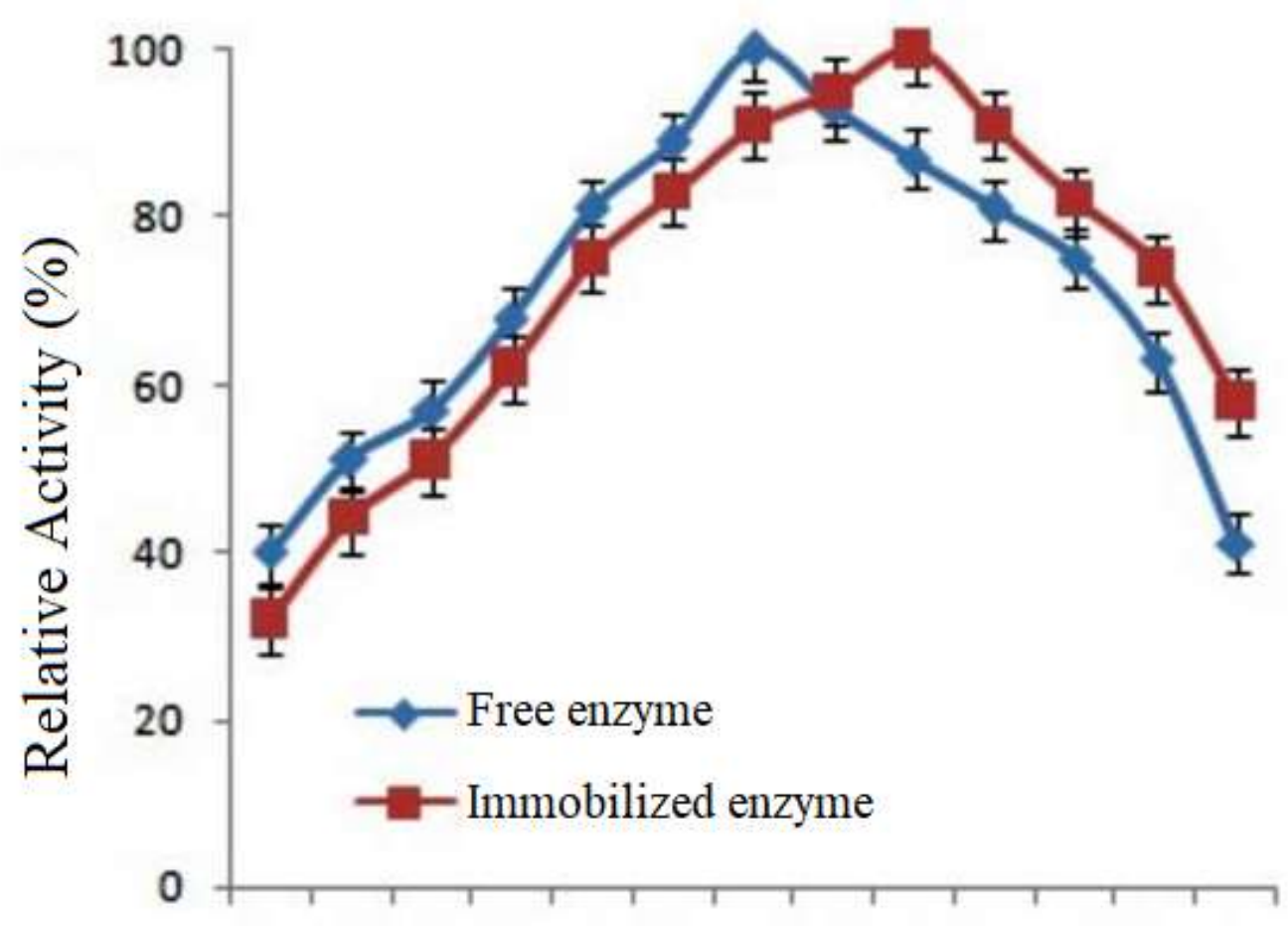

$\begin{array}{lllllllllllll}3 & 3.5 & 4 & 4.5 & 5 & 5.5 & 6 & 6.5 & 7 & 7.5 & 8 & 8.5 & 9\end{array}$

\section{$\mathrm{pH}$}

Figure 3. pH activity profile of the free and immobilized Aio. Error bars representing standard deviation of three values.

The influence of the temperature on the free and immobilized enzyme activity was investigated from $10^{\circ} \mathrm{C}$ to $50^{\circ} \mathrm{C}$ (with increment of $5^{\circ} \mathrm{C}$ ) to evaluate the enzyme stability (Figure 4). The optimum temperature shown by free and immobilized enzyme was $25^{\circ} \mathrm{C}$ and $35^{\circ} \mathrm{C}$ respectively. Immobilization has extended the temperature effect on enzyme activity and increased the enzyme stability. Temperature profile gets broadened after immobilization. Enzyme displayed gradual loss when the temperature was below $25^{\circ} \mathrm{C}$ and above $35^{\circ} \mathrm{C}$. The covalent bonding prevented conformational flexibility and provided more activation energy for proper reorganization. Therefore immobilized enzymes have shown more resistance towards higher temperature than free enzymes. Hoke and coauthors [35] has done each experiment at $20^{\circ} \mathrm{C}$ (as optimum temperature) for arsenite oxidase. Most effective temperature for arsenite biooxidation has been recorded as $25-28{ }^{\circ} \mathrm{C}$ where the enzyme showed highest potential [32]. 


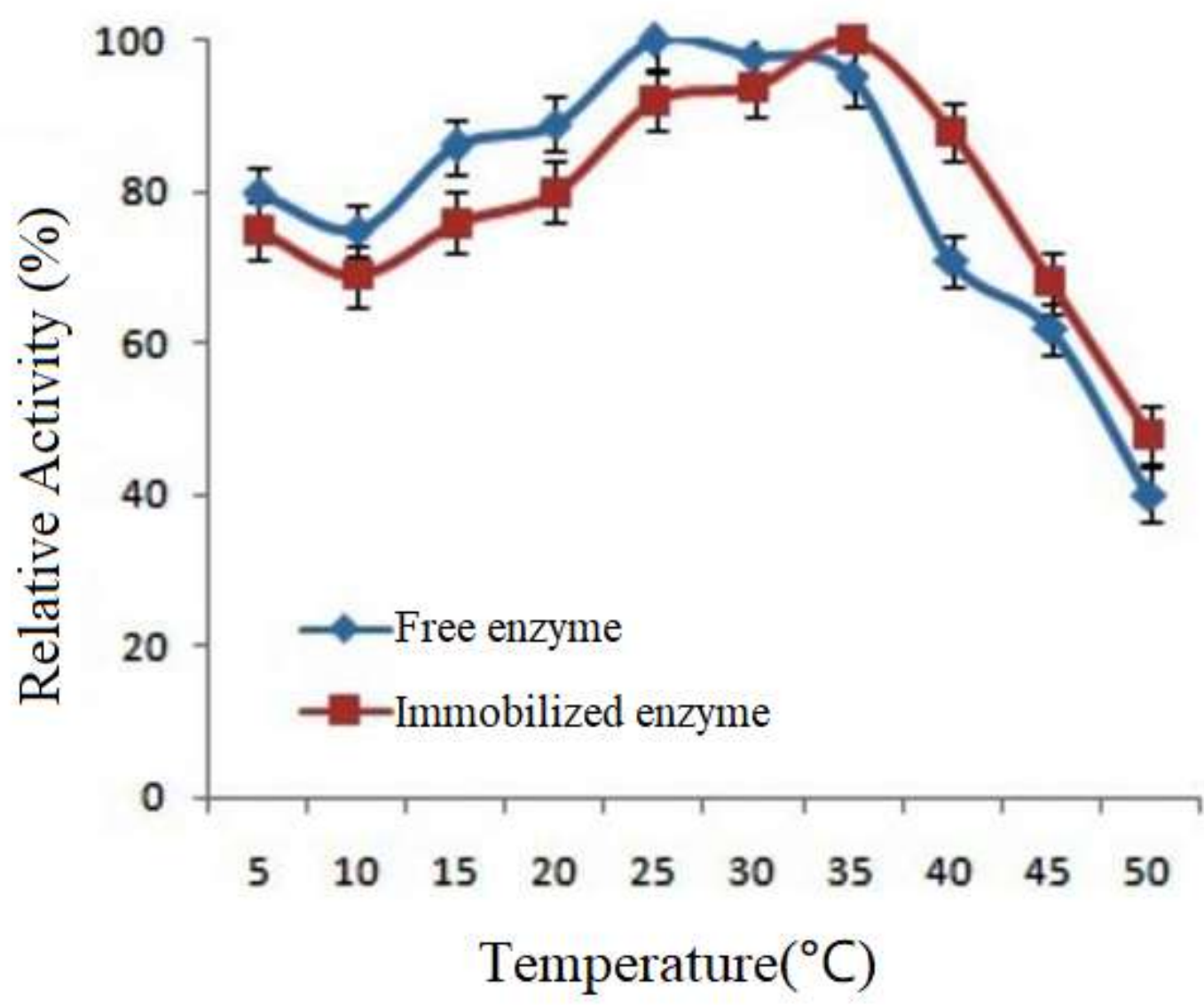

Figure 4. Temperature activity profile of the free and immobilized Aio. Error bars representing standard deviation of three values.

\section{Reusability and storage stability}

The residual activity of immobilized enzyme after continuous uses has been depicted in Figure 5 . The reusability of immobilized enzymes is advantageous over free enzymes in several applications. High expenses and lengthy time duration of enzyme production is being a major problem in industrial areas whereas the immobilized enzyme has the ability to recover from the substrate and reuse again [20]. Immobilized Aio strip showed high reusability and no visible losses during first three uses. After 4 uses, It showed decline behavior in enzyme activity. The declination may be occurred due to distortion of Aio from support material after repetitive use. The residual enzymatic activity retained was about $43 \%$ after ten continuous reuse of the immobilized strip. Hence, Aio immobilized PVC strip exhibits properties of thermal stability and reusability.

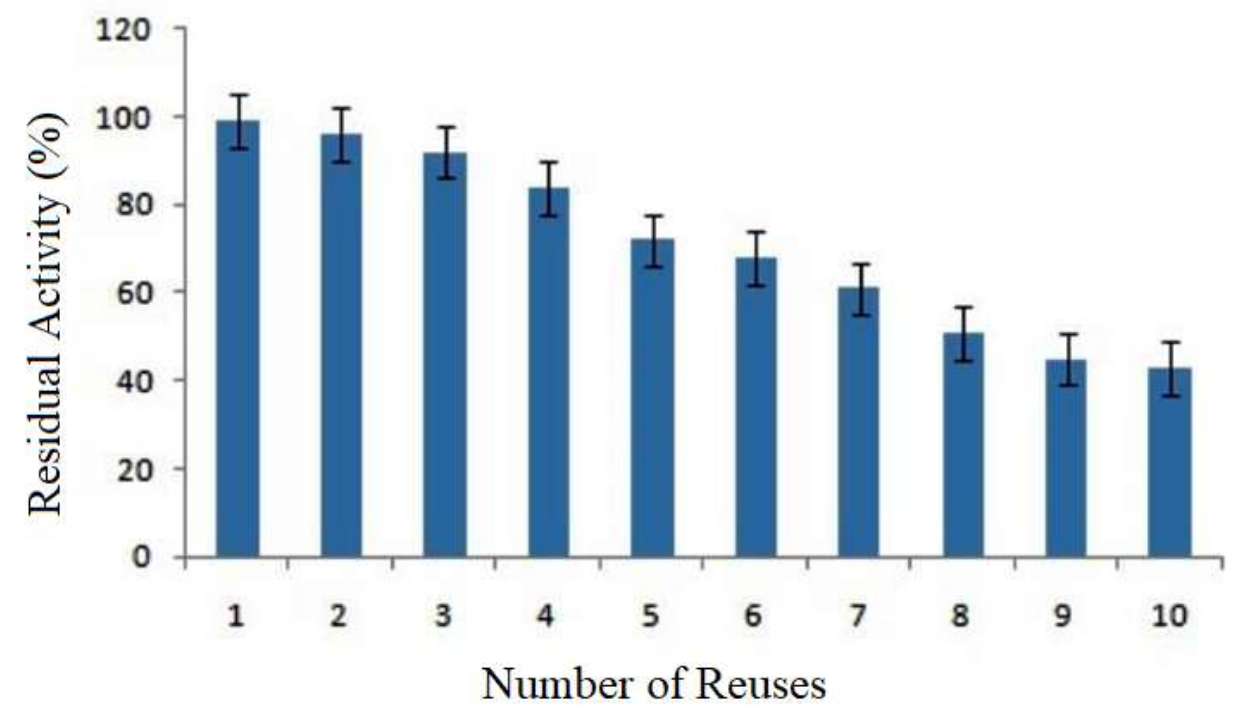


Figure 5. Reusability of the immobilized enzyme onto PVC strip. Error bars representing standard deviation of three values.

Storage stability represents the potential of biocatalyst of retaining its activity over a long duration. Thus, it is an important characteristic in practical utilization and in the commercialization of an enzyme [36]. It highly depends upon the immobilization support and the method used. Storage stability of free and immobilized Aio was evaluated over 30 days of time period and the activities retained were $17 \%$ and $52 \%$ respectively (Figure 6). Immobilization improved the storage capability by covalent bonding and stable enzyme conformation as compared to the free enzyme. Similar reports regarding enhancing storage stability of various enzymes upon immobilization has been also observed in previous researches $[37,38]$.

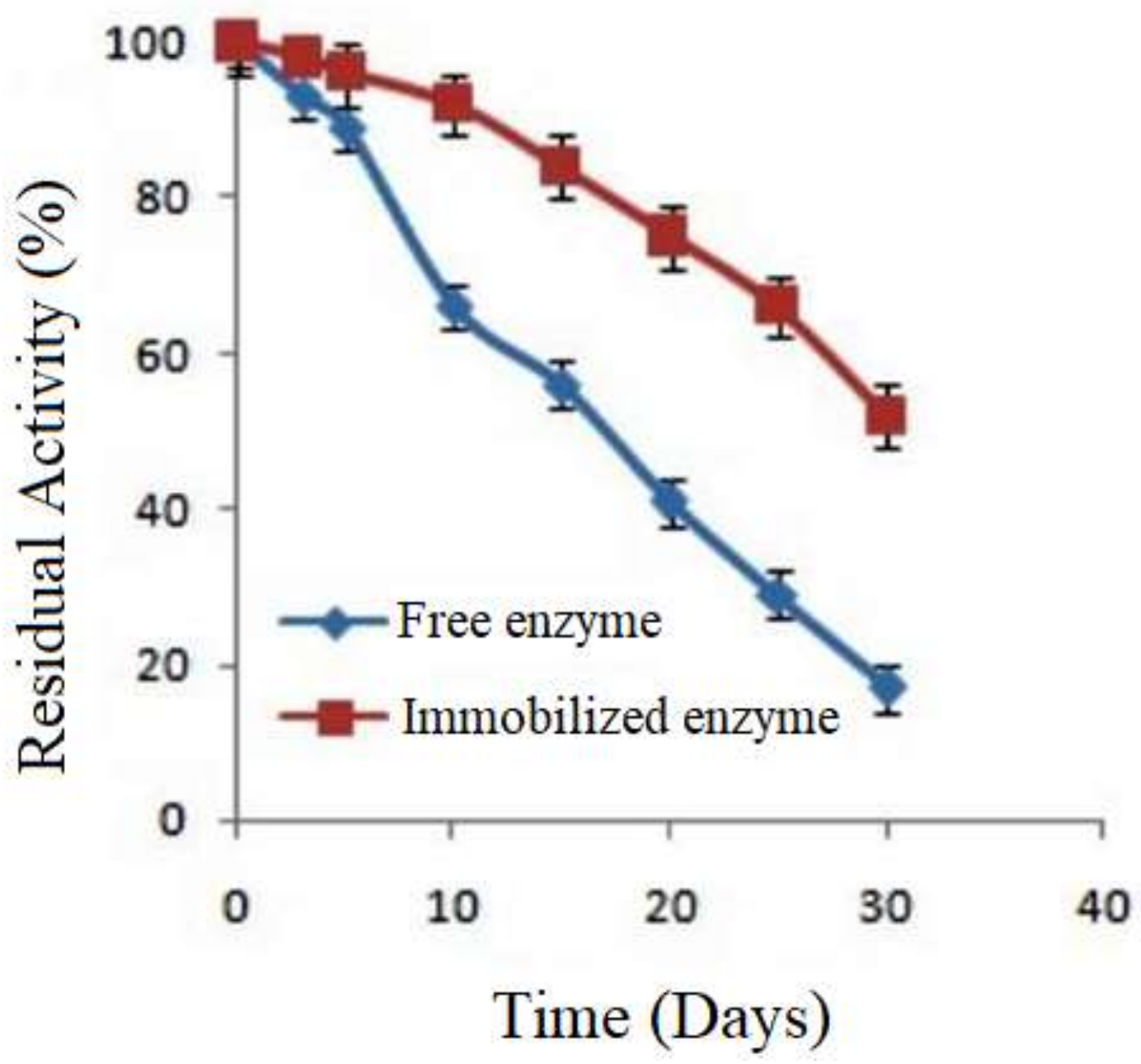

Figure 6. Storage stability of the free and immobilized Aio at $4{ }^{\circ} \mathrm{C}$ for 30 days. Error bars representing standard deviation of three values.

\section{Effect of interfering substances}

The influence on the activity of Aio by various metal ions (inhibitor/activator) was evaluated. Among the various substances investigated for possible interference, $1 \mathrm{mM}$ of $\mathrm{Na}^{+}, \mathrm{Fe}^{2+}, \mathrm{Ca}^{2+}, \mathrm{Mo}^{6+}$ and EDTA didn't show any effect and the enzyme was not inhibited by these metal ions. However, $\mathrm{Co}^{2+}, \mathrm{Zn}^{2+}$, lodoacetic acid and $p C M B$ inhibited the Aio and reduced the activity by $97,98.5,18$ and $12 \%$ respectively. Similar enzyme inhibition by copper metal ions has been reported by Male and coauthors [39] where he has observed its interference in different levels. Lace and coauthors [5] has reported that $\mathrm{Fe}^{2+}$ ions above $0.1 \mathrm{mg}^{-1}$ interfere with $\mathrm{As}^{3+}$ monitoring using the microfluidic detection system.

\section{Analytical recovery and precision}

To estimate the accuracy of the present method, the analytical recovery of added arsenic in the six samples was detected. The mean analytical recovery of added arsenic $(1 \mu \mathrm{g} / \mathrm{mL}$ and $2 \mu \mathrm{g} / \mathrm{mL})$ in sample was $98.7 \%$ and $97.2 \%$ respectively. Pena-Pereira and coauthors [40] has studied the recoveries by spiking 
water samples with arsenic at different concentrations and observed the recovery values for inorganic As in the range of 88 to $112 \%$. Lace and coauthors [5] has found the minimum percentage recovery i.e. $85.71 \%$ for $0.7 \mathrm{mg} \mathrm{L}-1 \mathrm{As}^{3+}$ sample and the maximum percentage recovery (122\%) for $1 \mathrm{mg} \mathrm{L}-1$ river water sample.

Reproducibility and authenticity of the present method was observed by detecting the level of arsenic concentration in six samples within a batch (in single run) and between batches i.e. after storage for one week at $-20^{\circ} \mathrm{C}$. The arsenic values obtained by these observations consented to one another and the result of within and between batch coefficients of variation (CVs) were $<2.35 \%$ and $<2.43 \%$.

\section{Application of newly developed method}

Multiple devices are used to detect arsenic based on enzyme and protein [41]. Strong bonds are formed by arsenic with sulfur thiolates in protein that either inhibits or enhances the protein function [42]. However, mainly protein based devices are significantly based upon enzyme inhibition that is useful for monitoring of heavy metals in liquid samples [43]. The levels of arsenic by using the present method were found between 4 and 53 ppb in water samples. Some samples do not show any presence of arsenic and hence detected by spike with 15ppb arsenic as a control. Similar evaluations have been observed by Male and coauthors [39] where the detection was done in no. of water samples and by Pena-Pereira and coauthors [40] in which the As was detected in four water samples of different complexity. Similar percentage recovery was shown by the water samples having same water matrix except some lake water samples because of several reasons affecting the microfluidic detection system. A broad range of many sample matrices would need to be estimated in future studies [5].

\section{CONCLUSION}

Owing to the toxicity of the arsenic in environment and human health, their detection is of paramount importance and remains a major challenge. Besides the methods used, enzyme based detection found to be reliable and accurate. Enzymes are known to have unique specificity and high sensitivity [44]. Hence, In the present study, PVC strip was used for the immobilization of purified Aio enzyme to enhance its biocatalytic efficiency and used for the arsenic detection. Purified Aio enzyme acquired specific activity of $0.83 \mu \mathrm{M}$ As(III)/min/mg and can be used for further applications efficiently. The immobilized enzyme oxidized As (III) to As (V) more rapidly than the native enzyme with high stability, sensitivity and efficient reusability. The prepared immobilized strip was capable of retaining almost $43 \%$ of its initial activity after using 10 times repeatedly. The optimum $\mathrm{pH}$ and temperature for immobilized enzyme were $\mathrm{pH} 7$ and $35^{\circ} \mathrm{C}$ respectively and showed stability in fluctuations. A rapid, sensitive and accurate analysis device for the arsenic using immobilized Aio enzyme was successfully accomplished. This can be considered more economic when compared with existing methods with better stability. Since PVC strip is economical, reproducible and efficient in electrochemical analysis, proves to be an apt and promising matrix for arsenic detection. Nanomaterials should be explored for developing versatile detection and activity enhancement. Further development should focus on modified approaches regarding in situ environmental monitoring.

Funding: This research received no external funding.

Conflicts of Interest: The authors declare no conflict of interest.

\section{REFERENCES}

1. Song L, Mao K, Zhou X, Hu J. A novel biosensor based on Au@ Ag core-shell nanoparticles for SERS detection of arsenic (III). Talanta. 2016;146:285-90.

2. Fendorf S, Michael HA, Van Geen A. Spatial and temporal variations of groundwater arsenic in South and Southeast Asia. Science. 2010;328(5982):1123-7.

3. Mays DE, Hussam A. Voltammetric methods for determination and speciation of inorganic arsenic in the environment-a review. Anal Chim Acta. 2009;646(1-2):6-16.

4. Chowdhury U K, Biswas TR, Chowdhury G, Samanta BK, Mandal GC, Basu C R, et al. Groundwater arsenic contamination in Bangladesh and West Bengal, India. Environ Health Perspect. 2000;108(5):393.

5. Lace A, Ryan D, Bowkett M, Cleary J. Arsenic detection in water using microfluidic detection systems based on the leucomalachite green method. Anal Methods. 2019;11(42):5431-8.

6. Haque R, Mazumder DG, Samanta S, Ghosh N, Kalman D, Smith MM, et al. Arsenic in drinking water and skin lesions: dose-response data from West Bengal, India. Epidemiology. 2003;174-82. 
7. Walvekar RR, Kane SV, Nadkarni MS, Bagwan IN, Chaukar DA, D'Cruz AK. Chronic arsenic poisoning: a global health issue-a report of multiple primary cancers. J Cutan Pathol. 2007;34(2):203-6.

8. Gumpu MB, Mani GK, Nesakumar N, Kulandaisamy AJ, Babu KJ, Rayappan JBB. Electrocatalytic nanocauliflower structured fluorine doped $\mathrm{CdO}$ thin film as a potential arsenic sensor. Sensor Actuat BChem.2016;234:426-34.

9. Zhou G, Pu H Pu, Chang J, Sui X, Mao S, Chen J. Real-time electronic sensor based on black phosphorus/Au NPs/DTT hybrid structure: Application in arsenic detection. Sensor Actuat B-Chem. 2018;257:214-9.

10. Hashem MA, Jodai T, Ohira SI, Wakuda K, Toda K. High sensitivity arsenic analyzer based on liquid-reagent-free hydride generation and chemiluminescence detection for on-site water analysis. Anal Sci. 2011;27(7):733.

11. Forzani ES, Foley K, Westerhoff $P, T a o N$. Detection of arsenic in groundwater using a surface plasmon resonance sensor. Sensor Actuat B-Chem. 2007;123(1):82-8.

12. Ackerman AH, Creed PA, Parks AN, Fricke MW, Schwegel CA, Creed JT, et al. Comparison of a chemical and enzymatic extraction of arsenic from rice and an assessment of the arsenic absorption from contaminated water by cooked rice. Environ Sci Technol. 2005;39(14):5241-6.

13. Hung DQ, Nekrassova $O$, Compton RG. Analytical methods for inorganic arsenic in water: a review. Talanta. 2004;64(2):269-77.

14. Bonyar A, Nagy P, Mayer V, Vitéz A, Gerecs A, Sántha H, et al. A colorimetry based, semi-automated portable sensor device for the detection of arsenic in drinking water. Sensor Actuat B-Chem. 2017;251:1042-9.

15. De Mora K, Joshi N, Balint BL, Ward FB, Elfick A, French CE. A pH-based biosensor for detection of arsenic in drinking water. Anal Bioanal Chem. 2011;400(4):1031-9.

16. Whiteley CG, Lee DJ. Enzyme technology and biological remediation. Enzyme Microb Tech. 2006;38(34):291-316.

17. Rao MA, Scelza R, Scotti R, Gianfreda L. Role of enzymes in the remediation of polluted environments. J Soil Sci Plant Nutr. 2010;10(3):333-53.

18. Talat M, Prakash O, Hasan SH. Enzymatic detection of As (III) in aqueous solution using alginate immobilized pumpkin urease: Optimization of process variables by response surface methodology. Bioresour Technol. 2009;100(19):4462-7.

19. Pandey N, Bhatt R. Improved biotransformation of arsenic by arsenite oxidase-Chitosan nanoparticle conjugates. Int J Biol Macromol. 2018;106:258-65.

20. Eş I, Vieira DG, Amaral AC. Principles, techniques, and applications of biocatalyst immobilization for industrial application. App Microbiol Biot. 2015;99(5):2065-82.

21. Schaefer A. Biosensors for quickly detecting arsenic in drinking water. Environ Sci Technol. 2003;37:378A-9A.

22. Ellis PJ, Conrads T, Hille R, Kuhn P. Crystal structure of the $100 \mathrm{kDa}$ arsenite oxidase from Alcaligenes faecalis in two crystal forms at 1.64 A and 2.03 A. Structure. 2001;9:125-32.

23. Bryan $C G$, Marchal $M$, Battaglia-Brunet $F$, Kugler $V$, Lemaitre-Guillier $C$, Lièvremont $D$, et al. Carbon and arsenic metabolism in Thiomonas strains: differences revealed diverse adaptation processes. BMC microbiol. 2009;9(1):127.

24. Warelow TP, Oke M, Schoepp-Cothenet Z, Dahl JU, Bruselat N, Sivalingam GN, et al. The respiratory arsenite oxidase: structure and the role of residues surrounding the rieske cluster. PLoS One. 2013;8(8).

25. Watsona C, Niksb D, Hilleb R, Vieirac M, Schoepp-Cothenetd B, Marquesc AT, et al. Electron transfer through arsenite oxidase: Insights into Rieske interaction with cytochrome c. BBA- Bioenergetics. 2017;1858:865-72.

26. Prasad KS, Subramanian V, Paul J. Purification and characterization of arsenite oxidase from Arthrobacter sp. Biometals. 2009;22(5):711.

27. Anderson GL, Williams J, Hille R. The purification and characterization of arsenite oxidase from Alcaligenes faecalis, a molybdenum-containing hydroxylase. J Biol Chem. 1992;267:23674-82

28. Bradford M. A rapid and sensitive method for the quantitation of microgram quantities of protein utilizing the principle of protein-dye binding. Anal Biochem. 1976;72:248-54.

29. Santini JM, Vanden Hoven RN. Molybdenum-containing arsenite oxidase of the chemolithoautotrophic arsenite oxidizer NT-26. J Bacteriol. 2004;186(6):1614-9.

30. Muller D, Lievremont D, Simeonova D, Hubert JC, Lett MC. Arsenite oxidase aox genes from a metal-resistant $\beta$ proteobacterium. J Bacteriol. 2003;185(1):135-41.

31. Marques ME, Mansur AA, Mansur HS. Chemical functionalization of surfaces for building three-dimensional engineered biosensors. App Surf Sci. 2013;275: 347-60.

32. Simeonova DD, Micheva K, Muller DA, Lagarde F, Lett MC, Groudeva VI, et al. Arsenite oxidation in batch reactors with alginate-immobilized ULPAs1 strain. Biotechnol Bioeng. 2005;91(14):441-6. 
33. Sanllorente-Méndez S, Domínguez-Renedo O, Arcos-Martinez MJ. Immobilization of acetylcholinesterase on screen-printed electrodes: application to the determination of arsenic(III), Sensors (Basel). 2010;10:2119-28.

34. Sanllorente-Méndez S, Domínguez-Renedo O, Arcos-Martinez MJ. Development of acid phosphatase based amperometric biosensors for the inhibitive determination of As(V). Talanta. 2012;93:301-6.

35. Hoke KR, Cobb N, Armstrong FA, Hille R. Electrochemical studies of arsenite oxidase: an unusual example of a highly cooperative two-electron molybdenum center. Biochem. 2004;43:1667-74.

36. Singh K, Kayastha AM. Optimal immobilization of $\alpha$-amylase from wheat (Triticum aestivum) onto DEAEcellulose using response surface methodology and its characterization. J Mol Catal B-Enzym. 2014;104:75-81.

37. Kumar S, Dwevedi A, Kayastha AM. Immobilization of soybean (Glycine max) urease on alginate and chitosan beads showing improved stability: Analytical applications. J Mol Catal B-Enzym. 2009;58:138-45.

38. Nawaz MA, Karim A, Aman A, Marchetti R, Qader SAU, Molinaro A. Continuous degradation of maltose: improvement in stability and catalytic properties of maltase ( $\alpha$-glucosidase) through immobilization using agar-agar gel as a support. Bioproc Biosyst Eng. 2015;38:631-8.

39. Male KB, Hrapovic S, Santini JM, Luong JH. Biosensor for arsenite using arsenite oxidase and multiwalled carbon nanotube modified electrodes. Anal Chem. 2007;79:7831-7.

40. Pena-Pereira F, Villar-Blanco L, Lavilla I, Bendicho C. Test for arsenic speciation in waters based on a paperbased analytical device with scanometric detection. Anal Chim Acta. 2018;1011:1-10.

41. Upadhyay LSB, Kumar N, Chauhan S. Minireview: Whole-cell, Nucleotide, and Enzyme Inhibition-based Biosensors for the Determination of Arsenic. Anal Lett. 2018;51(9):1265-79.

42. Zhang D, Zhao J, Li G. Protein-based voltammetric biosensors fabricated with nanomaterials. Protein Peptide Lett. 2008;15(8):764-71.

43. Ilangovan R, Daniel D, Krastanov A, Zachariah C, Elizabeth R. Enzyme based biosensor for heavy metal ions determination. Biotechn Biotechnol Equip. 2006;20(1):184-89.

44. Liu ZG, Huang XJ. Voltammetric determination of inorganic arsenic. TrAC Trends in Anal Chem. 2014; 60: 25-35. 2021 by the authors. Submitted for possible open access publication under the terms and conditions of the Creative Commons Attribution (CC BY NC) license (https://creativecommons.org/licenses/by-nc/4.0/). 